\title{
INDONESIAN CAPITAL MARKET REACTIONS FOR THE ELECTION OF DONALD TRUMP AS UNITED STATES PRESIDENT (EMPIRICAL STUDY ON MULTINATIONAL COMPANIES LISTED ON THE INDONESIA STOCK EXCHANGE)
}

\author{
Daniel Christhoper \\ Fakultas Ekonomi dan Bisnis, Universitas Padjajaran \\ Layyinaturrobaniyah \\ Fakultas Ekonomi dan Bisnis, Universitas Padjajaran \\ layyinaturrobaniyah@unpad.ac.id
}

\begin{abstract}
This study aims to determine the market reaction to the announcement of the Donald Trump as the elected President of the United States, as seen from the performance of the shares of multinational companies on the Indonesia Stock Exchange (BEI) and tests market efficiency in a half-strong form. This research uses purposive sampling technique with samples of 24 multinational companies and uses a market model to calculate abnormal return. The results show that first, there are significant average abnormal returns at $t-6, t-4, t-3, t-2$, then at $t+1$ to $t+7$ and negative cumulative average abnormal returns. Second, there are smaller but significant average abnormal returns after Donald Trumph's announcement as President of the United States than average abnormal returns before the announcement during the window period. Third, trading volume activity decreases significantly after the announcement of Donald Trump as the elected President of the United States. The results of the research prove that the market reacts to the announcement of Donald Trump as the elected President of the United States or it can be said that the announcement has a negative information content on the performance of the stock market represented by the stock performance of multinational companies. In addition, these results prove that the Indonesian capital market is not efficient in half-strong form due to information leakage and reaction that is quite slow in responding to the announcement of Donald Trump as the elected President of the United States.
\end{abstract}

Keywords: market reaction, abnormal return, public information, capital market efficiency.

\begin{abstract}
Abstrak
Penelitian ini bertujuan untuk mengetahui reaksi pasar terhadap pengumuman Donald Trump sebagai Presiden Amerika Serikat terpilih, seperti yang terlihat dari kinerja saham perusahaan multinasional di Bursa Efek Indonesia (BEI) dan menguji efisiensi pasar bentuk setengah-kuat. Penelitian ini menggunakan teknik purposive sampling dengan sampel 24 perusahaan multinasional dan menggunakan model pasar untuk menghitung return tidak normal. Hasil penelitian menunjukkan bahwa pertama, ada average return tidak normal yang signifikan pada $t-6, t-4, t-3, t-2$, kemudian pada $t+1$ hingga $t+7$ dan average return tidak normal kumulatif negatif. Kedua, ada average return tidak normal yang lebih kecil tetapi signifikan setelah pengumuman Donald Trumph sebagai Presiden Amerika Serikat daripada pengembalian abnormal rata-rata sebelum pengumuman selama periode jendela. Ketiga, aktivitas volume perdagangan menurun secara signifikan setelah pengumuman Donald Trump sebagai Presiden Amerika Serikat terpilih. Hasil penelitian membuktikan bahwa pasar bereaksi terhadap pengumuman Donald Trump sebagai Presiden Amerika Serikat terpilih atau dapat dikatakan
\end{abstract}


bahwa pengumuman tersebut memiliki kandungan informasi negatif pada kinerja pasar modal yang diwakili oleh kinerja saham perusahaan multinasional. Selain itu, hasil ini membuktikan bahwa pasar modal Indonesia tidak efisien dalam bentuk setengah-kuat karena kebocoran informasi dan reaksi yang cukup lambat dalam menanggapi pengumuman Donald Trump sebagai Presiden Amerika Serikat terpilih.

Kata Kunci: reaksi pasar, return tidak normal, informasi publik, efisiensi pasar modal. JEL: G14

\section{Research Background}

The capital market as an economic instrument becomes a place for investors to invest. Investors must be careful in considering and assessing the performance of companies that will become their investment choices, especially investments in the form of shares. All investors expect a return from the investment made. However, according to the principle of high risk high return, there is always a risk that must be prepared to be borne to get a return. Risk in investment can be interpreted as a result or a result that is different from expectations. In investment, risk cannot be avoided, but can be minimized. To minimize risk in investment, investors need information. The more accurate information is obtained, the easier for investors to make decisions and determine the expected return will be.

Investment in the capital market is strongly influenced by various information that is processed for investor decision making. Any relevant information that enters the market and relates to a stock will affect the supply and demand between sellers and buyers who form a new equilibrium price. Tandelilin (2010) says that efficient markets are markets where the prices of all traded securities reflect all available information. To conduct a half-strong efficiency test, an event study can be carried. Event study is an evaluation study which studies the market reaction to an event whose information is published as an event (Jogiyanto 2008). If an announcement has information, it is expected that a reaction will occur in the market. Market reactions can be measured from abnormal returns and trading volume activity.

Information that can affect the capital market comes not only from the economic sector, but also from the political sector. Events that occur in a country can also affect other countries as a result of globalization. Political events affect the future and policies that will be applied in a country. These policies can be taken into consideration by investors in investing in the country.

The event that allegedly will cause a reaction in the Indonesian capital market is the event of when Donald Trump is elected as President of the United States on November 9, 2016 due to strong economic relations between the United States and Indonesia. In addition, the United States currency is still a reference for almost all currencies of other countries so that what happens in the United States will greatly affect the economic conditions of other countries in the world, including Indonesia.

The CSPI (Composite Stock Price Index) movement showed a lowest point of 1,241 points in November 2008. The DJIA (Dow Jones Industrial Average) index was at its lowest point in the observation period in February 2009 at 7,062 points. The FTSE (Financial Times Stock Exchange) 100 index was at its lowest at 3,830 points in March 2009, but the IBEX 35 and ATHEX index were at their lowest point in May 2012, at 6,089 points and 525 points, respectively. Based on these conditions, it shows that the position of the lowest share price index in each exchange seems to form a separate group where the JCI, DJIA and FTSE 100 are at the lowest point in the adjacent period, namely in the period of late 2008 and early 2009 while the IBEX index 35 and ATHEX were in the same period in May 2012.

In the movement of the highest position of the stock price index of each capital market in the observation period there are also separate group differences. European capital markets are in the highest position in the adjacent period while the capital markets of Indonesia and the 
United States are in the adjacent period as well. The JCI was at the highest position at 4,350 points in October 2012 and the DJIA index was at the highest position at 13,437 points in September 2012. The indices in European capital markets such as the FTSE 100 and IBEX were in the highest position at 6,087 points and 13,798 points in April 2008. The ATHEX index was at its highest position at 4,362 points in January 2008.

The economic bonds between Indonesia and the United States can be seen from the results of several previous studies. Ruhendi and Arifin (2003) who revealed that the movement of the Dow Jones Index on the New York Stock Exchange had a positive influence on the movement of the Composite Stock Price Index. The integration between the Indonesian capital market and the United States, Japanese, Singapore and Chinese capital markets was also revealed in the research of Karim et al. (2009). Furthermore, Hardianto (2012) in his research also concluded that there was cointegration between the US stock price index (DIJA) and the Indonesia stock price index (CSPI) during the economic crisis in the United States and Europe in 2008-2012.

One of the United States policies relating to Indonesia is the fiscal cliff. The positive impact of the fiscal cliff is that many investors will invest in Indonesia because Indonesia is considered as a large market which is quite profitable to invest in the next 5-10 years with the availability of labor. However, the uncertainty of policies in the trade sector such as the export ban on several volatile commodities makes investors be more careful to invest. Meanwhile, sector that provides security is only in the capital market sector.

The elected of Donald Trump as President of the United States will certainly lead to many new policies. Economic relations and the United States exports will also be affected by the policies made by the new leader of the United States. Investors will anticipate and reevaluate investment in the capital market, especially multinational companies because multinational companies conduct business activities and place their production locations in several countries.

Based on the explanation above, the formulation of the problems to be answered in this study are: first, significance of average abnormal return around the elected of Donald Trump as President of the United States of America in a multinational company listed on the Indonesia Stock Exchange. Second, significance of difference in the average abnormal return between before and after the elected of Donald Trump as President of the United States of America in a multinational company listed on the Indonesia Stock Exchange. Third, significance of difference in the average trading volume activity before and after the elected of Donald Trump as President of the United States of America in a multinational company listed on the Indonesia Stock Exchange?

\subsection{Capital Market and Market Efficiency}

According to Tandelilin (2010), the capital market is a meeting between parties who have excess funds and parties who need funds by trading securities.

Fama (1970) in Tandelilin (2010) states that an efficient market is a market whose prices reflect relevant information; which means stock prices are difficult to predict. Published information can affect the price of securities in the capital market. The market is said to be halfefficient if the prices of securities fully reflect all published information including those in financial statements such as income, devidends, new product development, financial difficulties, or changes in the company's accounting data (Jones 2003). Public information can be devided into three, namely new information concerning one issuer, several issuers (industries), or all issuers. Tests for semi-strong forms, namely in the form of testing the speed of securities prices adjust to new information in the capital market, where the semi-strong form occurs if the investor cannot obtain the above-average risk-adjusted return consistently after the announcement of the information. If it turns out there is a difference in time to make adjustments to the announcement, and investors can take advantage of getting abnormal, which 
means the form of capital markets that occur are not fully efficient in the form of semi-strong. This semi-strong form efficiency test can be done using an event study.

\subsection{Event Study}

An event study is a study that studies the market reaction to information. This can find out whether the market is efficient or not. According to Tandelilin (2010), efficient market hypothesis is a theory that states that in an efficient market, securities prices are quickly evaluated by important information related to these securities. An event study can be used to test the information content of an announcement and can also be used to test the efficiency of an announcement. market. According to Jogiyanto (2008) if the announcement contains information, it is expected that the market will react when the announcement is received by the market. The market reaction is indicated by the change in prices of the securities in question or having relation with the announcement.

\subsection{Abnormal Return}

According to Jogiyanto (2008), abnormal return is the excess of the real return to the normal return which is the expected return by the investor. Abnormal return are often used as a basis for testing the information content of an event announcement that will eventually be used to test market efficiency. Abnormal return is the return obtained by investors that is not in line with expectations. Abnormal return are said to be positive if the return obtained is greater than the expected return or the calculated return. While abnormal return are said to be negative if the return obtained is smaller than the expected return or calculated return.

\subsection{Trading Volume Activity}

Trading volume activity (TVA) or volume of stock trading activities is a comparison of shares traded at a certain time with the number of shares circulating in the market. The volume of trading activity is a method to test the market reaction to information. Testing the reaction of the capital market using a volume approach to trading activities has been carried out by Beaver (1968). According to Husnan et al. (1996), the volume of stock trading activities can be used to see whether an investor individually assesses an event as an informative, in a sense, whether the information will make an investment decision that is different from the normal investment decision. An information contains an informative value if the number of shares traded is bigger or smaller when the event occurs, compared to the other times.

\subsection{Previous Research Study}

Alim and Santoso (2002) in his research concluded that the event of a presidential inauguration was not an event that had important information content for investors. While the research of Meidawati and Harimawan (2004) shows that the events of the 2004 Indonesian Legislative General Election affected the trading volume activity, but did not have a significant effect on abnormal returns. Suryawijaya and Setiawan (1998) stated that an increase in trading volume in the capital market as a form of capital market reaction to an event can have two meanings, namely bad news and good news.

Gede and Nyoman (2015) conducted a study of abnormal returns before, after, and at the time of the inauguration of Joko Widodo as the 7th President of Indonesia. The results showed that abnormal returns in the event period varied but were not statistically significant. This is similar to the results of research on the differences in market reactions before and after the inauguration of Joko Widodo as the $7^{\text {th }}$ President of the Republic of Indonesia. In other words, the inauguration of Joko Widodo as President of the 7th Republic of Indonesia did not contain meaningful information for investors, which made the market not react.

Another study was conducted by Savita and Ramesh (2015) regarding the reaction of the Indian capital market to the Indian General Election and the results showed that the event 
had an effect on the abnormal return and trading volume activity. Meanwhile, Kamilia (2016) who examined the reaction of several stock exchanges in ASEAN to the events of Britain Exit showed that there was no significant difference in the average abnormal return and there was no significant difference in the average trading volume activity.

\subsection{Hypothesis}

H1: There is a significant average abnormal return around the election of Donald Trump as President of the United States. H2: There is a difference in the average significant abnormal return before and after the event of the election of Donald Trump as President of the United States. H3: There is a significant difference in the average trading volume activity before and after the election of Donald Trump as President of the United States.

\section{Research Method}

This study uses an event study design to find out market reactions to the announcement of the election of Donald Trump as President of the United States. Market reaction is proxied by the appearance of abnormal returns and changes in trading volume activity around the event period which is 7 days before the announcement event and 7 days after. Meanwhile, the estimated period used is 30 days. Calculation of estimated abnormal returns uses a market model.

The sampling technique uses purposive sampling with a sample of 24 selected companies. The purposive sampling method is non-random sample selection whose information is obtained using certain considerations, which are generally adjusted to the objectives or research problems (Sugiyono 2013). Some of the criteria used in the selection of samples of this study are:

a. The sample is a multinational company. Multinational companies according to Certo (1997) are companies that have significant operations in more than one country.

b. The sample is a company that has never been delisted from the Indonesia Stock Exchange during the study period.

c. Samples do not make other announcements or corporate actions during the event period.

The data source in this study is secondary data where data can be obtained through the official website of the Indonesia Stock Exchange (www.idx.co.id), the Yahoo Finance website (finance.yahoo.com).

The following is a design analysis and hypothesis testing in this study calculate daily individual stock returns and market returns during the time window period, calculate $\alpha$ and $\beta$ using SPSS, calculate the expected return during the event period using the market model using the OLS (Ordinary Least Square) regression technique.

Notation:

$$
\mathbf{E}\left(\mathbf{R}_{\mathbf{i}} \mathbf{t}\right)=\text { á }+\boldsymbol{\beta i R} \mathbf{m t}
$$

$\mathbf{E}(\mathbf{R i t})$ : the expected return on securities $\mathrm{i}$ on the day $\mathrm{t}$

$\boldsymbol{\alpha}$ : intercept

Bi : graphic gradient coeeficient of security market line (SML)

Rmt: market rate of return on day $\mathrm{t}$ formula:

Calculate daily abnormal returns during the time window period with the following

$$
\begin{aligned}
& \qquad \mathbf{A R}_{\mathbf{i}} \mathbf{t}=\mathbf{R}_{\mathbf{i}} \mathbf{t}-\mathbf{E}\left(\mathbf{R}_{\mathbf{i}} \mathbf{t}\right) \\
& \text { Notation: } \\
& \mathbf{A R}_{\mathbf{i t}}: \text { abnormal return of the i-th stock during period } \\
& \mathbf{R}_{\mathbf{i t}}: \text { real Return of the i-th stock during period } t \\
& \mathbf{E}\left(\mathbf{R}_{\mathbf{i t}}\right) \text { :expected Return of the i-th stock during period } t
\end{aligned}
$$


Calculate the average daily abnormal return of all shares (ARit) during the time window period with the following formula:

Notation:

$$
\mathbf{A A R}_{\mathbf{i}, \mathbf{t}}=\frac{\sum_{\mathbf{i}=\mathbf{1}}^{\mathrm{k}} \mathbf{A} \mathbf{R}_{\mathbf{i}, \mathbf{t}}}{\mathbf{n}}
$$

$\mathbf{A} \mathbf{A} \mathbf{R}_{\mathbf{i}, \mathbf{t}}$ : average abnormal return at the $\mathrm{t}$-th day

$\mathbf{A R}_{\mathbf{i}, \mathbf{t}}$ :abnormal returnu for the i-th stock at the $\mathrm{t}$-th day

$\mathbf{k}$ : Number of securities affected by the event

Calculate the standard deviation of each day in the time window period with the following formula:

Notation:

$$
\mathrm{KSE}=\sqrt{\frac{\sum_{i=1}^{k}(A R i, t-A A R i, t)^{2}}{k-1}} \frac{1}{\sqrt{k}}
$$

KSE: Standard deviation for day $\mathrm{t}$

Calculate the standardized abnormal return of each stock during the time window period with the following formula:

Notation:

$$
\mathbf{S A R}=\frac{\mathbf{A R}_{\mathbf{i}, \mathbf{t}}}{\mathbf{K S E}}
$$

SAR: Standardized Abnormal Return

Determine t-calculated value with the formula as follows:

$$
\text { t calculated }=\frac{\sum S A R}{\sqrt{k}}
$$
formula:

Calculate the trading volume activity of individual daily stocks using the following

$$
\text { TVAit }=\frac{\text { Vi,t }}{\text { Vm,t }}
$$

Notation :

TVAit:Trading volume activity of $i$-th stock at the $t$-th day

$\mathbf{V i , t}$ : Quantity of the i-th stock traded at the t-th day

$\mathbf{V m}, \mathbf{t}$ : Quantity of the $i$-th stock traded at thr $t$-th day

Calculate the average of trading volume activity with the following formula:

Notation:

$$
\operatorname{ATVA}=\frac{\sum_{i=1}^{\mathrm{k}} \mathrm{TVA}_{\mathrm{it}}}{\mathbf{k}}
$$

ATVA : average of stock trading volume activity

$\sum_{\mathbf{i}=\mathbf{1}}^{\mathbf{k}} \mathbf{T V A}_{\mathbf{i t}}$ : Quantity of stock trading volume activity at day $\mathrm{t}$

$\mathbf{k} \quad:$ number of companies as samples

The testing of the hypothesis in this study is by one sample t-test to test the significance of abnormal return and trading volume activity around the event period and use the pired sample t-test to do a differecet test of abnormal return before and after the announcement at the 
level of significance $(\alpha)$ of $5 \%$.

\section{Result and Discussion}

The results of the research presented in Table 1 show that on the announcement day of Donald Trump as President of the United States there was a positive but not significant average abnormal return (AAR), while before the announcement there was a negative and significant AAR, i.e., at $\mathrm{t}-2, \mathrm{t}-3, \mathrm{t}-4$, and $\mathrm{t}-6$. After the announcement there is a negative and significant $\mathrm{AAR}$ at $\mathrm{t}+1$ and $\mathrm{t}+7$. These results indicate that at the time of the announcement the market actually responded positively only the magnitude of the existing AAR was not significant, until the $t+1$ AAR was then corrected by reacting negatively significantly. This shows that the announcement of the election of Donald Trump as President of the United States has a content of information (information content) that causes the market to react, so H1a in this study cannot be rejected. Overall during the period of market event, it reacts negatively as indicated by the CAAR value of -0.0160434 . But the market can be said to be inefficient in the form of halfstrong because a significant market reaction occurred before the announcement and a few days after the announcement.

Table 1. Average Abnormal Stock Return during Event Period

\begin{tabular}{cccccc}
\hline & N & AAR & CAAR & T hitung & $\begin{array}{c}\text { Signifikansi } \\
\text { AAR }\end{array}$ \\
\hline $\mathrm{t}-7$ & 24 & 0.00003275 & 0.0000327 & 0.016651 & \\
$\mathrm{t}-6$ & 24 & 0.00782759 & 0.0078603 & 1.661969 & $*$ \\
$\mathrm{t}-5$ & 24 & -0.00204042 & 0.0058199 & -0.72364 & \\
$\mathrm{t}-4$ & 24 & 0.01808716 & 0.0239071 & 2.76296 & $* * *$ \\
$\mathrm{t}-3$ & 24 & -0.00460626 & 0.0193008 & -1.56809 & $* *$ \\
$\mathrm{t}-2$ & 24 & -0.01019926 & 0.0091016 & -3.25807 & $* * *$ \\
$\mathrm{t}-1$ & 24 & 0.00221879 & 0.0113203 & 0.918727 & \\
$\mathrm{t} 0$ & 24 & 0.00123046 & 0.0125508 & 0.37857 & \\
$\mathrm{t}+1$ & 24 & -0.01212063 & 0.0004302 & -4.60732 & $* * *$ \\
$\mathrm{t}+2$ & 24 & -0.00623951 & -0.0058093 & -3.14045 & $* * *$ \\
$\mathrm{t}+3$ & 24 & -0.00571451 & -0.0115238 & -3.09688 & $* * *$ \\
$\mathrm{t}+4$ & 24 & 0.00822550 & -0.0032983 & -2.312492 & $* * *$ \\
$\mathrm{t}+5$ & 24 & -0.00432732 & -0.0076256 & -1.99553 & $* *$ \\
$\mathrm{t}+6$ & 24 & -0.00594333 & -0.0135690 & -2.32694 & $* * *$ \\
$\mathrm{t}+7$ & 24 & -0.00247444 & -0.0160434 & -1.75827 & $* *$ \\
\hline $\mathrm{S}$
\end{tabular}

Source: Data processed, 2018.

Notes :*: significant at $\alpha=10 \%(\mathrm{t}=1.319, * *$ : significant at $\alpha=5 \%(\mathrm{t}=1.714), * * *$ significant at $\alpha=$ $1 \%(\mathrm{t}=2.499)$.

The existence of significant reactions before the announcement of the election of Donald Trumps (i.e., at t-6, t-4, t-3, and t-2) indicate an information leak. Meanwhile, on the announcement of Donald Trumph's day there was no significant market reaction, the market just reacted significantly for seven days after the announcement, so it could be said that the announcement provided information that was useful for investors in decision making, only the reaction was spelled out quite slow. These results indicate that the market was in an inefficient category in the form of a half strong because investors react before the announcement and a few days after the announcement. The investor's reaction occurred before the announcement was made possible by investors who were considering news spread in the media about the competing presidential candidate, namely Hillary Clinton. The United States Federal Bureau of 
Investigation (FBI) decided to review the e-mails of Democratic Party candidate Hillary Clinton using a private server. This was decided after the FBI discovered new e-mails believed to be related to the Hillary e-mail scandal. This announcement appeared 11 days before the US presidential election was held and could potentially interfere the election of Hillary. The negative dominant stock performance after the announcement showed that information on the election of Donald Trump as President of the United States was included as negative news. This result also shows the reaction of investors who sell or release shares within a few days after information was announced by Donald Trump as President of the United States.

The results of this study are different from several previous studies which showed no significant influence around the announcement of general elections occurred in Indonesia. However, the results of this study are in line with the results of research conducted by Kamilia (2016) on the events of Great Britain Exit on several ASEAN stock exchanges which obtained significant results on several days after the event occurred. The results of the study are also slightly different from the research of Savita and Ramesh (2015) in general elections in Rizal (2005) in the 2004 General Election which stated that there was a significant reaction on the announcement day and concluded the market in the efficient category in the form of halfstrong.

The second hypothesis in this study was whether there were significant differences in abnormal return before and after the election of Donald Trump as President of the United States. Table 2 shows the difference in the average abnormal return (AAR) before and after the announcement of Donald Trump as President of the United States, where AAR before the announcement of Donald Trump as President of the United States was 0.00162 and after the announcement of Donald Trump as President of the United States was -0.00408 .

The results of the paired samples difference test showed that the $\mathrm{t}$-calculated value was 2.253276 with a significance level of 0.065147 (below 0.1). In this analysis, it is obtained the results of the second hypothesis formulation $\mathbf{H} 2_{\mathbf{0}}$ is rejected so that there can be a significant difference in the average abnormal return before and after the election of Donald Trump as President of the United States for the multinational companies listed on the IDX. The results of this study are different with several previous studies, namely the research of Allim (2002) on the Inauguration of Megawati Soekarno Putri as 5th President of Indonesia and Nyoman (2015) at the Inauguration of Joko Widodo as President of the 7th Republic of Indonesia which found that there were no significant abnormal returns before and after the events.

Table 2. Difference Test Results of Paired Sample T-Test AAR Before and After Announcement of the Election of Donald Trump as President of the United States.

\begin{tabular}{ccccccc}
\hline & N & Mean & $\begin{array}{c}\text { Mean } \\
\text { Differences }\end{array}$ & t & df & $\begin{array}{c}\text { Sig. (2- } \\
\text { tailed) }\end{array}$ \\
\hline AAR Before & 7 & 0.00162 & 0.005702 & 2.253276 & 6 & $0.065147^{*}$ \\
AAR After & 7 & -0.00408 & & & & \\
\hline
\end{tabular}

Source: Data processed, 2018.

Note.: *: significant level 10\% (0.1)

The third hypothesis in this study states that there is a significant difference in average trading volume activity before and after the election of Donald Trump as President of the United States. The following are the results of testing with paired sample t-test 


$\begin{aligned} & \text { Table 3: Difference Test Results of TVA Paired Sample T-Test Before and After the } \\
& \text { Announcement of Donald Trump's Choice as President of the United States }\end{aligned}$
\begin{tabular}{cccccccc}
\hline & N & Mean & $\begin{array}{c}\text { Mean } \\
\text { Differences }\end{array}$ & t & df & $\begin{array}{c}\text { Sig. (2- } \\
\text { tailed) }\end{array}$ \\
\hline ATVA Before & 7 & 0.003795 & 0.001593 & 2.610235 & 6 & $0.040108^{* *}$ \\
ATVA After & 7 & 0.002202 & & & & \\
\hline
\end{tabular}

Source: Data processed, 2018.

Note : **: significant level $5 \%(0.05)$.

Table 3 shows the difference in the value of trading volume activity (TVA) before and after the announcement of the election of Donald Trump as President of the United States. TVA before the announcement of the election of Donald Trump as President of the United States was 0.003795 and after the announcement of the election of Donald Trump as President was 0.002202 . The results of the difference test of paired samples show that the t-count value is 2.610235 with a significance level of 0.040108 (below 0.05). In this analysis the results of the second hypothesis formulation, i.e., $\mathbf{H} 3_{\mathbf{0}}$ are rejected so that there can be a significant difference in trading activity volume before and after the election of Donald Trump as President of the United States in multinational companies listed in the IDX. These results are in line with the research conducted by Meidawati and Harimawan (2004) on the announcement of the results of the 2004 Presidential Election which obtained significant differences before and after the announcement.

The Presidential Election Announcement of the United States is important information for investors to make decisions. Various survey institutions previously gave the results of temporary excellence that were always held by competing presidential candidates, namely Hillary Clinton. The results of the announcement that are different from these predictions can influence the reaction of investors. The investor receives information from the election and analyzes the impact to the company's stock performance. From the test results, investors are more dominant in making decisions to release their shares after receiving the announcement of the election of Donald Trump as President of the United States. The decision is taken by investors by considering policies that will be made by the new President of the United States. As a superpower country, the United States has a major influence on the international economy. Donald Trump's controversy in providing US vision, mission and strategy is a study for investors. With one of its plans to carry out a protectionist stance, it will affect the economic cooperation between Indonesia and the United States. Then indirectly, this attitude can affect the economic growth of other countries (for example: China, etc.) that have relations with multinational companies in Indonesia. Therefore, investors will use this announcement information for decisions to buy and sell shares of multinational companies they have.

\section{Conclusion}

There are market reactions that can be concluded in this study as follows: first, the dominantly negative market reaction that has been proxy abnormally indicates that the announcement of the election of Donald Trump as President of the United States contains information that is considered by investors. Market reaction appeared before information was announced, at the time of the announcement and the 4th day after the announcement. This indicates that the market is not efficient in the form of a half strong because of information leakage and also the market tends to be slow in responding to information because there are still negative and significant reactions in the period after the event date. Stock performance turned negative after the announcement of Donald Trump as President of America. Because the announcement is considered as bad news for investors. Second, there is a significant difference in trading volume activity, namely the decline in the volume of shares of multinational companies traded after the announcement of the election of Donald Trump as president of the 
United States. The decline in the volume of shares traded indicates that investor interest in multinational stocks declined, making it difficult to sell the company's shares.

\section{References}

Alim E, Santoso MW. 2002. Reaksi Pasar Modal Indonesia Terhadap Peristiwa Politik Dalam Negeri (Event Study: Peristiwa Pelantikan Megawati Soekarnoputri sebagai Presiden RI ke-5) [Skripsi]. Surabaya: Universitas Kristen Petra.

Beaver W. 1968. Market Price Financial Ratio and The Prediction of Failure. Journal of Accounting Research. 6(2): 179-193.

Certo SC. 1997. Supervision Quality, Diversity, and Technology. Chicago: Times Mirror Higher Education Group.

Gede B, Nyoman A. 2015. Reaksi Pasar Modal Indonesia Terhadap Peristiwa Politik (Event Study pada Peristiwa Pelantikan Joko Widodo Sebagai Presiden Republik Indonesia ke7) [Skripsi]. Denpasar: Universitas Pendidikan Ganesha.

Husnan S, Hanafi M, Wibowo A. 1996. Dampak Pengumuman Laporan Keuangan terhadap Kegiatan Perdagangan Saham dan Variabilitas Tingkat Keuntungan .Journal KELOLA. 5(11): 110-125.

IDX [internet]. 2019. Jakarta: IDX. [Cited in 2019 January 09]. Available from http://www.idx.co.id/id-id/beranda/perusahaantercatat/profilperusahaantercatat.aspx.

Jogiyanto. 2008. Teori Portofolio dan Analisis Investasi. Edisi kelima. Yogyakarta: BPFE.

Kamilia. 2016. Reaksi Pasar Saham di Beberapa Bursa Efek Asean Terhadap Peristiwa Britain To Exit (Brexit) di Eropa (Event Study Pada Indeks Saham Indonesia, Malaysia, Singapura, Filipina, dan Thailand) [Skripsi]. Bandar Lampung: Univeritas Lampung.

Karim BA, Majid MSA, Karim SAA. 2009. Financial Integration between Indonesia and Its Major Trading Partners [Internet]. [Cited in 2019 January 12]. Available from https://mpra.ub.uni-muenchen.de/26976/.

Meidawati, Harimawan. 2004. Pengaruh Pemilihan Umum Legislatif Indonesia Tahun 2004 Terhadap Return Saham dan VolumePerdagangan Saham LQ-45 di PT. Bursa Efek Jakarta (BEJ). Sinergi KajianBisnis dan Manajemen. 7(1): 89-101.

Rizal. 2005. Reaksi Pasar Modal (BEJ) Indonesia Terhadap Peristiwa Politik di Dalam Negeri (Event Study Pengaruh Peristiwa Pemilu Legislatif, Pilpres I, dan Pilpres II terhadap Perdagangan Saham LQ-45 dan Index LQ-45) [Tesis]. Jakarta: Universitas Indonesia.

Ruhendi, Arifin. 2003. Dampak Perubahan Kurs Rupiah dan Indeks Saham Dow Jones di New York Stock Exchange Terhadap Indeks Harga Saham Gabungan di BEJ. Wahana. 6(1): $1-12$.

Savita, Ramesh. 2015. Return Volatility Around National Elections: Evidence from India [Skripsi]. Roorke: Indian Institute of Technology.

Sugiyono. 2013. Metode Penelitian Pendidikan. Cetakan ke-16. Bandung: Alfabeta.

Suryawijaya, Setiawan. 1998. Reaksi Pasar Modal Indonesia Terhadap Peristiwa Politik dalam Negeri (Event study pada peristiwa 27 Juli 1996). Journal Kelola. 7(18): 137-153.

Tandelilin E. 2010. Portofolio dan Investasi. Edisi Pertama. Yogyakarta: Kanisius. 